\title{
TREATMENT OF GOUT BY REDUCTION OF URIC ACID PRODUCTION
}

\author{
BY \\ G. D. KERSLEY \\ Bath
}

For the interval treatment of gout the uricosuric agents have been until recently the only drugs of real value. Used continuously they have proved very effective, after a preliminary period of some 6 weeks when attacks are often exacerbated. Sulphinpyrazone (Anturan) is generally the most efficient and least toxic (Kersley and Gibbs, 1960); the effect is excellent even after over 5 years' administration, but relapse is immediate as soon as the drug is discontinued. The only frequent complication of the use of uricosuric agents is the production of calculi or gravel.

Recently three types of drug have been suggested to reduce uric acid production: caparase, oroturic acid, and the xanthine oxidase inhibitor, allopurinol. The use of the last-named in particular may well prove a major advance in the therapy of certain cases of gout.

\section{Present Investigations}

A pilot experiment has been carried out to compare the clinical and biochemical effects of caparase, oroturic acid, and allopurinol, and this has been followed by a more extensive trial of the longer-term effects of allopurinol, used both alone and together with anturan.

Caparase (Hepatocatalsase).-This drug is said by Barceló (1964) to catalyse the oxidation of the C2 and C8 atoms of the formic acid nucleus and the C5 atom from formate before its combination with glycine. Its effects are to reduce plasma uric acid levels and to reduce uricosuria, and also to lower serum cholesterol and blood sugar levels. It is recommended in a dosage of 10,000 units intramuscularly daily for the first month, with reduction thereafter to three injections weekly for another 3 months or more. The plasma uric acid level may begin to fall by the 5 th day and should be at its lowest after 2 to 3 weeks. The attack rate should gradually decrease and the duration of benefit varies inversely with the duration of treatment. Suppositories of 5,000 units are now available.

Oroturic Acid (Uracil 6-ethanoic acid). - This drug has been used by Delbarre (1964), and has been found to reduce the plasma uric acid level without affecting the uricosuria. It is thought to act by utilizing phosphoribosyl pyrophosphate, thus preventing feed-back and production of uridylic acid and uric acid synthesis (uridylic acid-inosinic acid-nucleic acid-hypoxanthine and uric acid). Chu and Malmgren (1964) have, however, found that mice treated with oroturic acid developed metastases when given mammary tumour cells intravenously more frequently than untreated controls.

Allopurinol (Xylopurin or HPP, 4 hydroxypyrozolo 3, 4-d pyramidine). - This is a potent inhibitor of xanthine oxidase and reduces the production of uric acid from xanthine and hypoxanthine. It causes a reduction in plasma uric acid levels and reduces uricosuria, but produces an increase in urinary oxypurines, which latter are incidentally more soluble than uric acid (Rundles, Wyngaarden, Hitchings, Elion, and Silberman, 1963). It has been suggested that, as the increased excretion of oxypurine does not appear sufficient to match the lowering of uric acid in the blood and urine, there may be some re-utilization of oxypurine or inhibition of synthesis of inosinic acid. Allopurinol was first used to prevent oxidation of 6-mercaptopurine in the treatment of leukaemia. In the therapy of gout, Yü and Gutman (1964), using $300 \mathrm{mg}$. per day, found a tendency for the attack rate to increase during the first 6 weeks of administration, as with benemid and anturan; a few cases also had slight diarrhoea. Hall, Holloway, and Scott (1964) reported two patients who developed slight rashes. Both groups of authors reported a satisfactory reduction in plasma uric acid levels with a fall in trinary uric acid and an increase in oxypurine excretion where estimated. The total purine plus oxypurine excretion was not greatly changed. Wyngaarden (1965) reported a transitory drop in the white blood cell count and Houpt (1965) found a temporary increase in the attack rate in six and very marked increase in two out of a series of twenty cases. Smyth (1965) reported that allopurinol with anturan had 
proved valuable in four exceptionally severe cases of gout. Ogryzlo (1965), in a series of twenty cases, found marked benefit and negligible toxicity.

\section{Pilot Study}

Four cases of gout were treated, after a control period, with caparase 10,000 units daily, oroturic acid 4 g. per day, and allopurinol $400 \mathrm{mg}$. per day for periods of 6 days each while the plasma uric acid levels and urinary uric acid and oxypurine excretion were estimated. With caparase, there was an average drop in plasma uric acid of $0.85 \mathrm{mg}$. per cent. and the urinary uric acid and oxypurine were slightly decreased. With oroturic acid, the plasma uric acid fell on an average by $2 \mathrm{mg}$. per cent., with a negligible increase in uricosuria, but a marked increase in urinary oxypurines. With allopurinol there was a marked drop in plasma uric acid by $3.5 \mathrm{mg}$. per cent., a decreased excretion of uric acid (from 753 to $473 \mathrm{mg}$. per day) and a doubled excretion of oxypurines (Figure).

\section{Allopurinol}

Because of the difficulty in obtaining caparase and the disadvantage of large daily injections, and because of the risk of carcinogenesis in the use of oroturic acid, it was decided to proceed with a longer-term experiment with allopurinol only, with and without the uricosuric agent anturan.

29 cases of gout were treated with allopurinol, $400 \mathrm{mg}$. per day, for upwards of 3 months, and four for more than a year. Eleven of these patients had previously been receiving anturan $600 \mathrm{mg}$. daily and for the first 6 months continued on both drugs with clinical benefit. Three of these, while remaining $\triangle$ reasonably well on the anturan from the point of $\$$ view of gout symptoms, still showed some rise in $\overrightarrow{0}$ plasma uric acid despite this medication. When allopurinol was given in addition, the plasma uric $\vec{\omega}$ acid fell at once from $9 \cdot 0$ to $4 \cdot 6$, from $6 \cdot 2$ to $3 \cdot 5$, and from 7.2 to $2.6 \mathrm{mg}$. per cent. respectively. 흥 One patient was clinically quite uncontrolled and $N$ had large discharging tophi and frequent incapaci- $\rightarrow$ tating attacks, but since starting the combined of treatment, the tophi have tended to heal and become $\omega$ smaller and the patient himself has improved greatly. 은

Five patients, who had had periodic gravel or $\vec{c}$ passed small calculi at frequent intervals, while on anturan, were transferred to allopurinol alone, with relief of their urinary symptoms.

Seven of the patients who at first had anturan and allopurinol together for 6 months, have now dropped

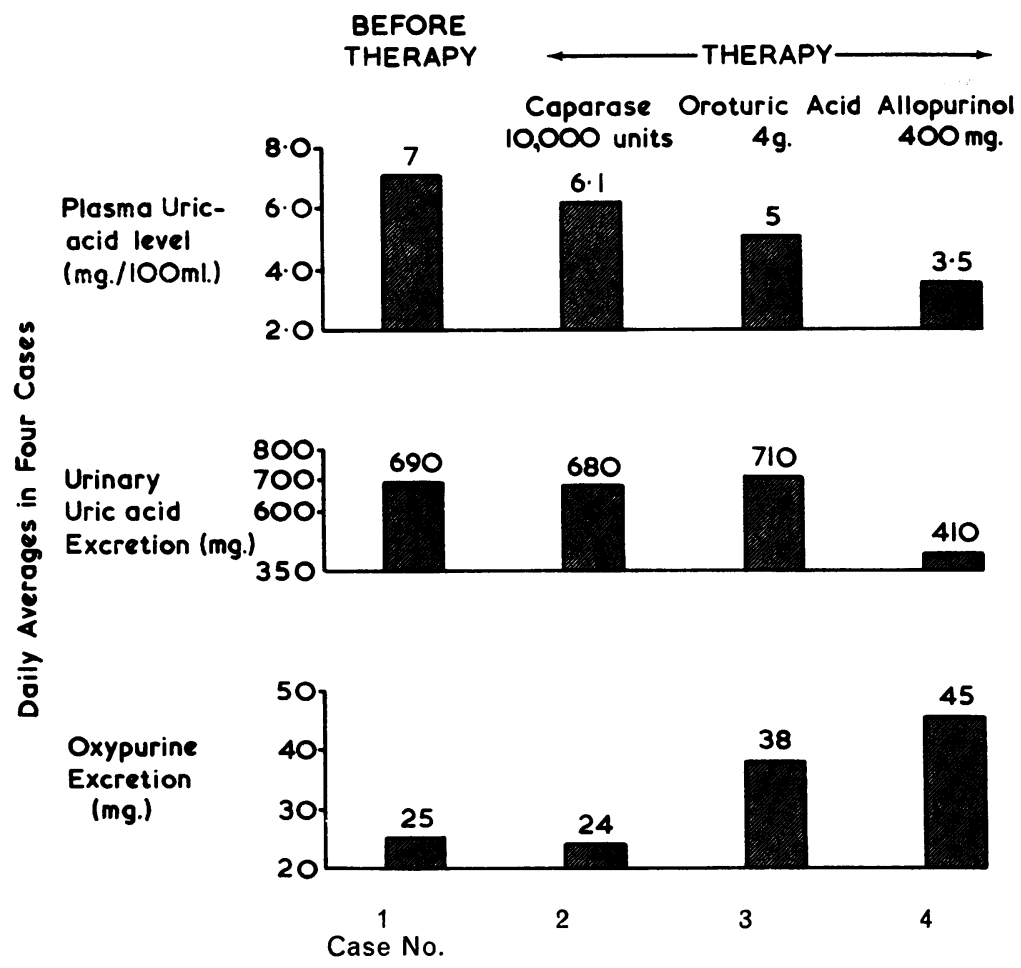

Figure.-Effect of three drugs claimed to reduce uric acid production on mean plasma uric acid level, ando urinary uric acid and oxypurine ex- $\vec{D}$ cretion in four cases of gout before and after therapy. 
the anturan and are progressing satisfactorily on allopurinol alone.

The four original patients who started taking allopurinol a year ago have now stopped taking the drug for a trial period. After a month the plasma uric acid levels are tending to rise, but less rapidly than is usual on stopping the uricosuric agents, and so far attacks of gout have restarted in only one of them.

During the first six weeks of administration, there was a slight tendency to exacerbation of symptoms, but this was considerably less than had previously been found with the uricosuric agents, and was easily controlled by a regular dosage of $1.5 \mathrm{mg}$. of colchicine daily, which is now given as a routine during this period. In the unusual event of a severe attack, it was rapidly terminated by the use of phenylbutazone.

In this series, there were no severe toxic symptoms. In two cases there was a slight rash, but in one this was found to be due to indomethacin prescribed by his general practitioner, and in the other the rash disappeared when the allopurinol was stopped and did not return when the drug was restarted. One patient experienced dyspepsia, but this did not occur when the tablets were taken with food.

In six cases serial SGOTs were estimated for 6 months and in eleven cases differential white blood cell counts, haemoglobin, and reticulocytes were estimated. In three cases there was a transitory drop in white blood cells of approximately 30 per cent., but the count returned to the pre-treatment level within 3 months in all of them without changing the dosage of allopurinol. There was no evidence of damage to the liver or blood-forming tissues.

\section{Conclusions}

Our findings suggest that the xanthine oxidase inhibitor allopurinol is likely to be of special clinical value in combination with anturan in the worst cases of gout not controlled by the latter drug alone, when gravel or calculi are a complication, and probably also in helping to prevent renal changes in gout. So far no dangers or contraindications are apparent. Allopurinol when used alone has a beneficial effect on gout, after a preliminary period of some 6 weeks, but further experience is necessary before an opinion can be given as to its relative value and safety as compared with the uricosuric agents in uncomplicated gout.

\section{Summary}

A study has been made of the clinical and biochemical effects of three types of drug in the reduc- tion of uric acid production: caparase, oroturic acid, and the xanthine oxidase inhibitor, allopurinol.

A pilot experiment with four cases of gout was followed by a long-term study of 29 cases treated with allopurinol alone and in combination with anturan.

The findings suggest that allopurinol with anturan is valuable in treating severe cases of gout and in helping to prevent renal damage. It may also be used alone with advantage in certain selected cases.

\section{REFERENCES}

Barceló, P. (1964). Arch. interamer. Rheum., 7, 218. Chu, E. W., and Malingren, R. A. (1964). Cancer Res., 24, 671 .

Delbarre, F. (1964). Arch. interamer. Rheum., 7, 230.

Hall, A. P., Holloway, V. P., and Scott, J. T. (1964). Ann. rheum. Dis., 23, 439.

Haupt, J. B. (1965). Arthr. and Rheum., 8, 899.

Kersley, G. D., and Gibbs, A. R. (1960). Ann. rheum. Dis., 19, 351

Ogryzlo, M. A. (1965). IX int. Congr. Rheum.

Rundles, R. W., Wyngaarden, J. B., Hitchings, G. H., Elion, G. B., and Silberman, H. R. (1963). Trans. Ass. Amer. Physcns, 76, 126.

Smyth, C. J. (1965). Arthr. and Rheum., 8, 907.

Wyngaarden, J. B. (1965). Ibid., 8, 883.

Yü, T. F., and Gutman, A. B. (1964). Amer. J. Med. 37,885 .

Traitement de la goutte, par la réduction de la production de l'acide urique

\section{RÉSUMÉ}

On étudia les effets cliniques et biochimiques de trois types de médicaments réduisant la production de l'acide urique: la caparase, l'acide oroturique et l'allopurinol, inhibiteur de l'oxidase xanthine.

Une expérience préliminaire avec quatre cas fut suivie d'une étude plus ample de 29 cas, traités par l'allopurinol seul et combiné à l'anturan.

Les résultats indiquent que l'allopurinol avec anturan est utile pour traiter des cas sévères de goutte et pour empêcher des lésions rénales. On peut aussi l'employer seul dans certains cas choisis.

El tratamiento de la gota con la reducción de la producción del ácido úrico

\section{SUMARIO}

Se estudiaron los efectos clínicos y bioquímicos de tres tipos de medicamentos que reducen la producción del ácido úrico: carapasa, ácido oroturico y allopurinol, inhibidor de la oxidasa xantina.

Investigaciones preliminares de cuatro casos fueron seguidos de un estudio a termino largo de 29 casos, tratados con allopurinol solo y asociado con anturan.

Los resultados indican que el allopurinol con anturan es útil en el tratamiento de casos graves de gota y para impedir lesiones renales. En ciertos casos seleccionados se le puede también emplear solo. 